\title{
PERSPEKTIF WISATAWAN DOMESTIK TERHADAP KUALITAS PELAYANAN WISATA ARUNG JERAM DI SUNGAI AYUNG, BALI
}

\author{
Ni Putu Evi Wijayanti', I Nyoman Darma Putra², \\ Ni Made Eka Mahadewi ${ }^{3}$ \\ 1,3 Sekolah Tinggi Pariwisata (STP) Nusa Dua \\ 2 Universitas Udayana
}

\begin{abstract}
This study aims to determine the perspective of domestic tourists of the quality services of the whitewater rafting at Ayung River, Bali, and their influence the level of tourist satisfaction. The variables measured in this study consisted of 23 indicators of service aspects that is part of five dimensions: physical evidence, reliability, responsiveness, assurance, empathy. The method of analysis data used to determine the level of satisfaction of domestic tourists in this research is the Importance Performan Analysis (IPA) and illustrated with Cartesian diagram. The results of this research shows that the 23 indicators of the service aspect were tested there are 15 aspects of service that have not met the expectations of tourists or tourists do not feel satisfied and eight aspects of service that has been providing value satisfied for domestic tourists. Indicators are not given satisfaction scores need to be given attention and treatment of all parties in form of efforts needs to be done to improve the quality of service so that satisfaction can be achieved.
\end{abstract}

Keyword : Perspective, quality of service, tourist satisfaction and Ayung River rafting.

\begin{abstract}
Abstrak
Penelitian ini bertujuan untuk mengetahui perspektif wisatawan domestik terhadap kualitas pelayanan wisata arung jeram di Sungai Ayung, Bali, dan pengaruhnya terhadap tingkat kepuasan wisatawan. Variabel yang diukur dalam penelitian ini terdiri dari 23 indikator dari aspek pelayanan yang merupakan bagaian dari lima dimensi yaitu: bukti fisik (tangible), kehandalan (reliability), daya tanggap (responsiveness), jaminan (assurance), empati (empathy). Metode analisis data yang digunakan untuk mengetahui tingkat kepuasan wisatawan domestik dalam penelitian ini adalah Importance Performan Analysis (IPA) yang digambarkan dengan diagram kartesius. Hasil pe-
\end{abstract}


nelitian ini menggambarkan bahwa dari 23 indikator aspek pelayanan yang diuji ada 15 aspek pelayanan yang belum memenuhi harapan wisatawan atau wisatawan belum merasa puas dan 8 aspek pelayanan yang sudah memberikan nilai kepuasan bagi wisatawan domestik. Indikator yang belum memberikan nilai kepuasan perlu diberikan perhatian dan penanganan dari semua pihak berupa upaya-upaya yang perlu dilakukan untuk meningkatkan kualitas pelayanan sehingga kepuasan dapat tercapai.

Keyword: perspektif, kualitas pelayanan, kepuasan wisatawan dan arung jeram Sungai Ayung.

\section{Latar Belakang}

Dalam tiga dekade terakhir ini, wisata arung jeram (white water rafting) berkembang di Indonesia. Perkembangan wisata alam ini bermula di Bali awal 1990-an, berlanjut ke berbagai tempat di Indonesia seperti Jawa Barat, Sulawesi Selatan, dan Sumatera. Di Bali, rafting di Sungai Ayung yang paling pertama berkembang dan paling terkenal. Wisatawan yang menggemari atraksi wisata ini tak hanya wisatawan asing tetapi juga wisatawan domestik.

Artikel ini menganalisis mengetahui perspektif wisatawan domestik terhadap kualitas pelayanan wisata arung jeram di Sungai Ayung, Bali, dan pengaruhnya terhadap tingkat kepuasan wisatawan. Tujuan penelitian dicapi dengan menjawab tiga pertanyaan berikut. Pertama, bagaimanakah perspektif wisatawan domestik terhadap kualitas pelayanan wisata arung jeram di Sungai Ayung. Kedua, bagaimana dimensi kualitas pelayanan mana saja yang perlu mendapat prioritas penanganan utama sesuai dengan tingkat kepentingan kinerja perusahaan arung jeram terhadap kualitas pelayanan di Sungai Ayung. Ketiga, upaya-upaya apakahg yang perlu dilakukan dalam meningkatkan kualitas pelayanan wisata arung jeram di Sungai Ayung terhadap kepuasan wisatawan domestik.

Penelitian ini secara umum bertujuan untuk mengkaji dan memahami perspektif wisatawan domestik terhadap kualitas pelayanan wisata arung jeram di Sungai Ayung dari segi lima dimensi kualitas pelayanan yaitu reliability, responsiveness, assurance, empathy,tangible.

\section{Wisata Arung Jeram di Bali}

Wisata arung jeram di Bali diawali pada tahun 1989 yang diperkenalkan oleh Sobek Expedisi. Kegiatan ini diawali dengan melakukan observasi tentang potensi sungai-sungai di Bali yang dapat dikembangkan menjadi lokasi kegiatan arung jeram oleh tim Sobek. Pada waktu itu Sungai Ayung 
dipilih sebagai lokasi yang cocok untuk kegiatan arung jeram bagi pemula dan sejak itu Sobek mulai menawarkan kegiatan arung jeram sebagai kegiatan petualangan yang bersifat leisure. Pada tahun 1994 diadakan kejuaraan nasional arung jeram yang resmi pertama kali di Sungai Ayung dengan menerapkan standar internasional yang kemudian dianggap pemicu kebangkitan wisata arung jeram di Bali hingga sekarang.

Popularitas arung jeram ditandai dengan pembentukan organisasi profesional penggemar. Terbentuknya Federasi Arung Jeram Indonesia (FAJI) pada tahun 1996 menjadi salah satu titik tolak naiknya perkembangan wisata arung jeram di Indonesia. Hal ini diawali dengan banyaknya bermunculan perkumpulan atau klub arung jeram yang menjadi ladang utama bagi perusahan arung jeram sebagai operator rafting (Faji.news.com, 2016). Indonesia memiliki 81 perusahaan arung jeram yang tergabung dalam FAJI dan tersebar dibeberapa daerah di Indonesia.Wahana dalam kegiatan arung jeram terdiri dari perahu karet, kayak, kano, dayung, life jacket dan helm. Tujuan arung jeram bisa dilihat dari sisi olah raga, rekreasi, dan ekspedisi.

Di Bali beroperasi 22 perusahaan arung jeram yang tergabung dalam Asosiasi Gabungan Pengusaha Wisata Bahari (Gahawisri) dengan tiga sungai yang beroperasi untuk wisata arung jeram yaitu; Sungai Ayung di Kabupaten Gianyar, Sungai Melangit di kabupaten Klungkung, dan Sungai Telaga Waja di Kabupaten Karangasem. Tingkat kesulitan sungai untuk aktifitas arung jeram terdiri dari 6 tingkatan, dari enam tingkatan tersebut yang paling sering dijadikan tempat kegiatan arung jeram adalah tingkat ke dua sampai tingkat ke empat, karena aman bagi peserta pemula dan yang berkeinginan untuk bersenang-senang (leisure). Sedangkan tingkat ke lima sampai ke enam memiliki tantangan yang ekstrem dan sangat berbahaya sehingga khusus bagi peserta yang sudah mahir dan professional di bidang arung jeram.

Tabel 1. Jumlah Wisatawan Domestik yang Berarung Jeram di Tiga Sungai di Bali, $2011-2015$

\begin{tabular}{|c|c|c|c|c|c|c|c|c|c|c|}
\hline Keterangan & 2011 & $\%$ & 2012 & $\%$ & 2013 & $\%$ & 2014 & $\%$ & 2015 & $\%$ \\
\hline Sungai Ayung & 52,313 & & 71,243 & 26,57 & 78,493 & 9,24 & 82,473 & 4,82 & 83,886 & 1,68 \\
\hline Sungai Telaga Waja & 32,259 & & 36,169 & 10,8 & 35,783 & $-1,07$ & 36,385 & 1,65 & 43,879 & 17,08 \\
\hline Sungai Melangit & 2,615 & & 2,194 & $-19,18$ & 1,156 & $-89,7$ & 2,426 & 52,3 & 1,291 & $-87,9$ \\
\hline Total & 87,187 & & 109,606 & 20,5 & 115,432 & 5,04 & 121,284 & 4,82 & 129,056 & 6,02 \\
\hline
\end{tabular}

Sumber : Gahawisri Provinsi Bali, 2015

Pertumbuhan jumlah wisatawan domestik yang membeli paket arung jeram di masing-masing lokasi mengalami fluktuasi seperti di Sungai Ayung mengalami pertumbuhan paling tinggi pada tahun 2012 sebesar 26,5\%, Sungai Telaga Waja pada tahun 2015 sebesar 17,0 \% dan Sungai Melangit 
pada tahun 2014 sebesar 52,3\%. Hal ini dipengaruhi oleh profil dan karakter Sungai Ayung sangat cocok bagi wisatawan domestik dan wisatawan yang pertama kali melakukan kegiatan wisata arung jeram atau lebih dikenal dengan pemula.

\section{Teori dan Metode}

Untuk membedah masalah penelitian di atas, penulis menggunakan beberapa teori dan konsep. Konsep yang digunakan diantaranya: Konsep persepsi dan ekspektasi konsumen, Konsep wisata arung jeram. Penelitian ini menggunakan beberapa teori yang relevan dalam menganalisis dimensi-dimensi kualitas pelayanan (servqual) yang mempengaruhi kepuasan wisatawan domestik terhadap kualitas pelayanan arung jeram di Sungai Ayung, Bali.

Adapun teori yang digunakan yaitu teori persepsi, teori kualitas pelayanan dan teori kepuasan konsumen. Dalam produk wisata arung jeram terdiri dari dua jenis yakni produk nyata (tangible) dan produk tidak nyata (intangible), Produk tidak nyata adalah segala sesuatu yang berhubungan dengan pelayanan dan citra (image) suatu produk yang dihasilkan oleh perusahaan.

Data primer dalam penelitian ini adalah data yang diperoleh dari penyebaran angket kepada wisatawan domestik yang menikmati produk dan pelayanan wisata arung jeram di Sungai Ayung. Teknik pengumpulan data dilakukan dengan menyebarkan angket pertanyaan yang relevan dengan rumusan permasalahan dengan metode purposive sampling, dimana yang akan menjadi responden adalah para wisatawan domestik yang berumur di atas 17 tahun. Penelitian ini menggunakan Skala Likert sebagai acuan dalam penyusunan angket yang disebarkan kepada responden. Responden diminta untuk memberikan tanggapan pada setiap pertanyaan dengan memilih lima pilihan jawaban. Dalam penelitian ini akan mengambil 100 sampel yang kemudian disebut sebagai responden.

Lokasi penelitian adalah di kawasan Sungai Ayung. Sungai Ayung terletak diantara perbatasan dari kabupaten Badung di sisi sebelah barat dan kabupaten Gianyar dari sisi sebelah timur. Lokasi arung jeram di Sungai Ayung meliputi 4 kecamatan, 9 kelurahan atau perbekel, 19 banjar, sedangkan jumlah perusahaan arung jeram yang berlokasi di Sungai Ayung berjumlah 13 perusahaan yaitu Sobek Bali Utama Rafting, Bali Adventure Rafting, Ayung River Rafting, Ubud Rafting, Puri Experience Adventure Rafting, Sari Profit Rafting, New Gangga Rafting, Mega rafting, Payung Rafting, Toekad Rafting, Graha Adventure Rafting, Rejeki Ayung Rafting, Surya Dewata Rafting.

Variabel yang diukur dalam penelitian ini terdiri dari 23 indikator dari aspek pelayanan yang merupakan bagaian dari lima dimensi yaitu: bukti fisik 
(tangible), kehandalan (reliability), daya tanggap (responsiveness), jaminan (assurance), empati (empathy). Metode analisis data yang digunakan untuk mengetahui tingkat kepuasan wisatawan domestik dalam penelitian ini adalah Importance Performan Analysis (IPA) dan digambarkan dengan diagram kartesius dengan nilai tingkat kinerja sebagai sumbu $\mathrm{X}$ (horizontal) dan nilai tingkat kepentingan sebagai sumbu Y (vertikal). Pembagian kuadran dalam grafik dapat dilakukan dengan menetapkan titik tolak (X,Y) yang dilalui dua garis berpotongan tegak lurus sehingga terbagi menjadi IV kuadran, yaitu kuadran I (prioritas utama), kuadran II (pertahankan prestasi), kuadran III (prioritas rendah), kuadran IV ( berlebihan).

\section{Data Responden}

\subsection{Karakteristik Responden Menurut Asal Wisatawan}

Tabel 2 Karakteristik Responden Menurut Asal Wisatawan

\begin{tabular}{|c|c|c|c|}
\hline 1. Jawa Barat ...22 Org (22\%) & 5. Padang & 7 Org & 9. Makasar 5 Org \\
\hline 2. Jawa Tengah 12 Org (2\%) & 6. Palembang & g $5 \operatorname{Org}(5 \%)$ & 10. Ambon \\
\hline 3. Jawa Timur 19 Org (19\%) & 7. Medan & 7 Org $\quad(7 \%)$ & 11.Batam \\
\hline 4. Bali 4 Org (4\%) & 8. Manado & 6 Org & 12. Pontianak 3 Org \\
\hline
\end{tabular}

Menurut Tabel 2 jumlah responden yang tertarik melakukan kegiatan arung jeram kebanyakan berasal dari Pulau Jawa karena di Pulau Jawa kegiatan arung jeram merupakan kegiatan yang tidak asing bagi mereka dan lokasi arung jeram juga banyak terdapat di sana, sehingga mereka tertantang untuk mencoba kegiatan tersebut di lokasi yang berbeda.

\subsection{Karakteristik Responden Berdasarkan Jenis Kelamin}

Diagram 1. Karakteristik Responden Berdasarkan Jenis Kelamin

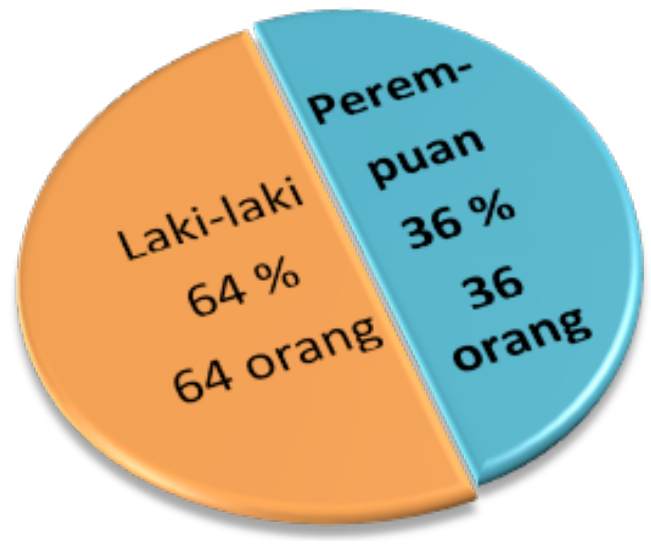

(Sumber : Hasil Pengolahan data, 2016) 
Diagram 1 menunjukkan bahwa 64\% wisatawan domestik yang berjenis kelamin laki-laki tertarik melakukan kegiatan wisata arung jeram dibandingkan wisatawan perempuan. Tantangan adrenalin yang muncul dari aktivitas ini menjadi motivasi tersendiri bagi wisatawan laki-laki.

\subsection{Karakteristik Responden Berdasarkan Umur Wisatawan}

Diagram 2. Karakteristik RespondenBerdasarkan Umur

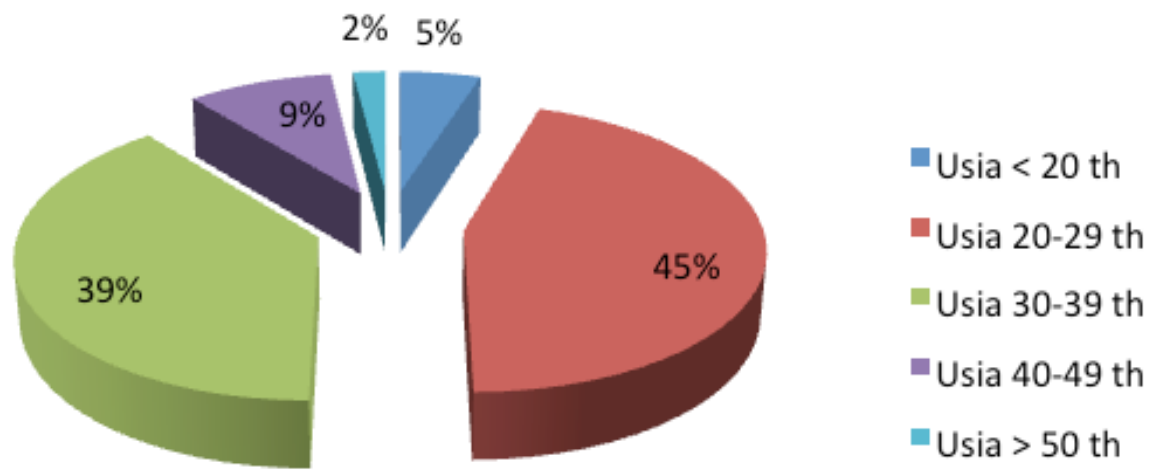

Sumber: Hasil Pengolahan Data, 2016

Pada diagram 2 tergambar data responden berdasarkan umur, dimana hasilnya didominasi oleh wisatawan berumur 20 tahun hingga 29 tahun, sebesar $45 \%$, karena wisatawan dengan usia tersebut rata-rata memiliki kondisi fisik yang kuat, serta rasa ingin tahu yang tinggi mengenai sesuatu hal yang baru seperti mengunjungi daerah baru yang memiliki kondisi alam yang menantang.

\subsection{Karakteristik Responden Berdasarkan Latar Belakang Pendidikan}

Tabel 3 menyatakan bahwa Komposisi kaum muda dengan latar belakang S1 yang mendominasi karena dipengaruhi oleh faktor ekonomi, minat akan pengalaman berpetualang dan waktu luang yang tersedia sehingga memotivasi wisatawan untuk melakukan kegiatan arung jeram.

\subsection{Karakteristik Responden Berdasarkan Pekerjaan}

Diagram 3 menggambar bahwa karakteristik responden menurut pekerjaan atau kegiatan utamanya didominasi oleh pegawai swasta (40\%), hal ini dipengaruhi oleh keinginan untuk mengisi waktu luang, relaksasi diri dan melepaskan diri sejenak dari kejenuhan rutinitas pekerjaan sehari-hari. 
Tabel 3. Karakteristik Responden Berdasarkan Latar Belakang Pendidikan

\begin{tabular}{clcc}
\hline No & \multicolumn{1}{c}{ Pendidikan } & Jumlah (Orang) & Presentase (\%) \\
\hline 1. & Non Pendidikan & 0 & 0 \\
2. & SD & 0 & 0 \\
3. & SMP & O & 0 \\
4. & SMA/SMK & 22 orang & $22 \%$ \\
5. & Diploma & 2 orang & $2 \%$ \\
6 & Sarjana S1 & 56 orang & $56 \%$ \\
7 & Pasca Sarjana & 20 orang & $20 \%$ \\
\hline
\end{tabular}

Sumber: Hasil Pengolahan data, 2016

Diagram 3. Karakteristik RespondenBerdasarkan Pekerjaan
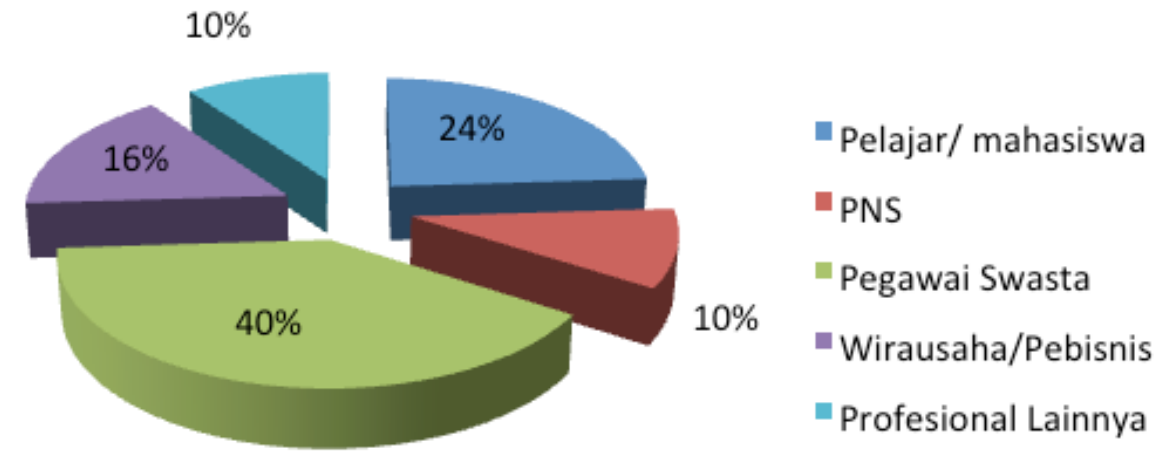

\subsection{Karakteristik Responden Berdasarkan Frekuensi Kegiatan Arung Jeram}

Rata-rata wisatawan domestik yang tertarik melakukan kegiatan arung jeram adalah para pemula atau yang baru pertama kali melakukan kegiatan arung jeram. Berdasarkan hasil wawancara dan kuesioner sebagian besar responden yang melakukan kegiatan wisata arung jeram di Sungai Ayung adalah pemula sebesar $56 \%$.

\section{Hasil Pembahasan}

\subsection{Hasil Perspektif Wisatawan Domestik}

Hasil analisis servqual yang bersumber dari nilai rata-rata ekspektasi dan nilai rata-rata persepsi wisatawan terhadap aspek pelayanan yang diberikan oleh pihak perusahan arung jeram, dimana ada beberapa aspek pelayanan yang dirasakan sangat memuaskan sehingga aspek tersebut memiliki kualitas yang baik. Selain itu diperoleh juga aspek pelayanan yang mendapat penilaian paling rendah atau tingkat kepuasan yang paling rendah sehingga dapat dikatagorikan sebagai aspek yang bekum memiliki kualitas yang baik. Data hasil persepsi wisatawan domestik dapat dilihat pada gambar berikut: 
Grafik 1. Karakteristik Responden Berdasarkan Frekuensi Melakukan Kegiatan Arung Jeram

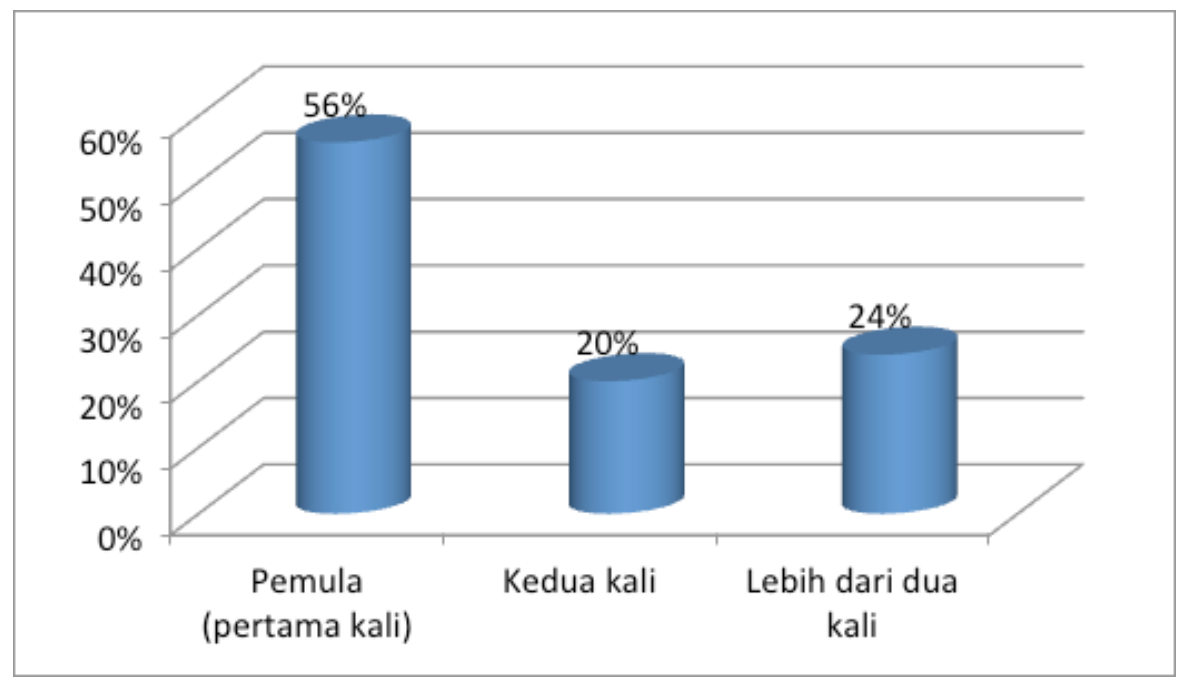

( Sumber: Hasil Pengolahan data, 2016)

Gambar 1 Nilai Standar Tingkat Kepuasan Wisatawan.

\section{Kualitas Pelayanan:}

1. Harapan $<$ Kenyataan $\Rightarrow$ (Kualitas sangat Memuaskan

2. Harapan $=$ Kenyataan $\Rightarrow$ (Kualitas Memuaskan $)$

3. Harapan $>$ Kenyataan $\Rightarrow$ (Kualitas tidak memuaskan)

\section{Kepuasan dapat dinyatakan sebagai berikut:}

1. NS $>0$, Harapan lebih dari terpenuhi (Sangat Puas)

2. $\mathrm{NS}=0$, Harapan terpenuhi (Puas)

3. NS $<0$, Harapan tidak terpenuhi ( Tidak Puas / Belum puas )

Menurut tabel 4 ada 23 aspek pelayanan yang dinilai oleh wisatawan domestik, dimana nilai kepuasan yang paling tinggi terdapat pada aspek keakraban antara karyawan dan wisatawan/hubungan relasi antara konsumen dengan karyawan dengan nilai o,29 dan aspek pelayanan yang memiliki nilai paling rendah adalah aspek kejernihan dan debit sungai dengan nilai $(-0,35)$. Nilai kepuasan wisatawan terhadap seluruh indikator aspek pelayanan yang diberikan pihak perusahaan arung jeram di Sungai Ayung terdapat selisih nilai $(-0,07)<0$. Hal ini mengartikan bahwa kualitas pelayanan pada perusahan arung jeram tersebut belum sepenuhnya mampu memenuhi harapan wisatawan atau wisatawan belum merasa terpuaskan 
Tabel 4 Hasil Rata-Rata Nilai Persepsi, Ekspektasi dan Kepuasan Wisatawan Domestik Terhadap Aspek Pelayanan Pada Perusahaan Arung Jeram di Sungai Ayung

\begin{tabular}{|c|c|c|c|c|c|c|}
\hline No & Aspek Pelayanan & $\begin{array}{c}\text { Rata-ra- } \\
\text { ta }\end{array}$ & $\begin{array}{c}\text { Rata-ra- } \\
\text { ta } \\
\text { NE }\end{array}$ & $\begin{array}{c}\begin{array}{c}\text { Ra- } \\
\text { ta-rata }\end{array} \\
\text { NS }\end{array}$ & Ket & $\begin{array}{l}\text { Nilai / } \\
\text { Dimensi }\end{array}$ \\
\hline \multicolumn{7}{|c|}{ A. Dimensi Bukti Fisik (Tangibles) : } \\
\hline 1 & Kebersihan fisik Gedung Kantor & 3,75 & 3,85 & $-0,10$ & Belum Puas & \\
\hline 2 & $\begin{array}{l}\text { Kebersihan Tempat Makan (restauran) } \\
\text { dan Coffe break }\end{array}$ & 3,84 & 4,15 & $-0,31$ & Belum Puas & \\
\hline 3 & $\begin{array}{l}\text { Kebersihan Ruang ganti, Kamar mandi, } \\
\text { dan Toilet }\end{array}$ & 3,88 & 4,02 & $-0,14$ & Belum Puas & \\
\hline 4 & $\begin{array}{l}\text { Kebersihan dan Kenyamanan Ruang tung- } \\
\text { gu dan Tempat Parkir }\end{array}$ & 3,86 & 3,89 & $-0,03$ & Belum Puas & \\
\hline 5 & Penampilan Karyawan & 3,89 & 3,95 & $-0,06$ & Belum Puas & \\
\hline 6 & Perlengkapan $\mathrm{P}_{3} \mathrm{~K}$ & 3,78 & 3,67 & $\mathbf{0 , 1 1}$ & Sangat Puas & \\
\hline 7 & $\begin{array}{l}\text { Ketersediaan media informasi, Saluran } \\
\text { telepon, email dan kotak saran }\end{array}$ & 3,70 & 3,85 & $-0,15$ & Belum Puas & \\
\hline 8 & Panorama sepanjang aliran Sungai Ayung & 4,15 & 4,19 & $-0,04$ & Belum Puas & \\
\hline \multirow[t]{2}{*}{9} & Kejernihan dan debit Sungai Ayung & 3,75 & 4,10 & $-0,35$ & Belum Puas & \\
\hline & Nilai rata-rata & 3,84 & 3,96 & $-0,12$ & Belum Puas & $-0,12$ \\
\hline \multicolumn{7}{|c|}{ B. Dimensi Kehandalan (Reliability): } \\
\hline 10 & $\begin{array}{l}\text { Kemampuan karyawan dalam memberikan } \\
\text { pelayanan }\end{array}$ & 3,87 & 4,00 & $-0,13$ & Belum Puas & \\
\hline 11 & $\begin{array}{l}\text { Ketersediaan material informasi berupa } \\
\text { brosure dan pamflet }\end{array}$ & 3,90 & 4,14 & $-0,24$ & Belum Puas & \\
\hline 12 & $\begin{array}{l}\text { Ketepatan waktu pelaksanaan kegiatan } \\
\text { arung jeram }\end{array}$ & 3,65 & 3,83 & $-0,18$ & Belum Puas & \\
\hline 13 & $\begin{array}{l}\text { Peralatan yang digunakan sesuai dengan } \\
\text { standar keselamatan dan kenyamanan } \\
\text { wisatawan }\end{array}$ & 3,85 & 4,15 & $-0,30$ & Belum Puas & \\
\hline 14 & $\begin{array}{l}\text { Fasilitas yang tersedia dapat berfungsi } \\
\text { dengan baik }\end{array}$ & 3,88 & 3,77 & $\mathbf{0 , 1 1}$ & Sangat Puas & \\
\hline & Nilai rata-rata & 3,83 & 3,98 & $-0,15$ & Belum puas & $-\mathbf{0 , 1 5}$ \\
\hline \multicolumn{7}{|c|}{ C. Dimensi Daya Tanggap (Responsiveness): } \\
\hline 15 & $\begin{array}{l}\text { Respon karyawan terhadap keluhan } \\
\text { wisatawan }\end{array}$ & 3,60 & 3,68 & $-0,08$ & Belum Puas & \\
\hline & Nilai rata-rata & 3,60 & 3,68 & $-0,08$ & Belum Puas & $-\mathbf{0 , 0 8}$ \\
\hline \multicolumn{7}{|c|}{ D. Dimensi Jaminan (Assurance) } \\
\hline 16 & Karyawan sopan dan ramah & 3,82 & 3,82 & 0,00 & Puas & \\
\hline 17 & $\begin{array}{l}\text { Karyawan aktif berkomunikasi dengan } \\
\text { wisatawan }\end{array}$ & 3,72 & 3,70 & $\mathbf{0 , 0 2}$ & Sangat Puas & \\
\hline 18 & Kejujuran karyawan & 3,66 & 3,73 & $-0,07$ & Belum Puas & \\
\hline 19 & $\begin{array}{l}\text { Karyawan memiliki pengetahuan dan } \\
\text { kecakapan tentang produk arung jeram }\end{array}$ & 3,86 & 3,86 & 0,00 & Puas & \\
\hline 20 & $\begin{array}{l}\text { Memiliki jaminan asuransi bagi kesela- } \\
\text { matan wisatawan }\end{array}$ & 3,95 & 4,10 & $-0,15$ & Belum Puas & \\
\hline \multirow[t]{2}{*}{21} & Keamanan wisatawan dan barang bawaan & 3,88 & 3,88 & 0,00 & Puas & \\
\hline & Nilai rata-rata & 3,82 & $\mathbf{3 , 8 5}$ & $-\mathbf{0 , 0 3}$ & Belum puas & $-\mathbf{0 , 0 3}$ \\
\hline
\end{tabular}

\begin{tabular}{|c|c|c|c|c|c|c|}
\hline \multicolumn{7}{|c|}{ E. Dimensi Empati (Empathy) } \\
\hline 22 & $\begin{array}{l}\text { Keakraban antara karyawan dengan wisa- } \\
\text { tawan / hubungan relasi antara konsumen } \\
\text { dengan karyawan }\end{array}$ & 3,65 & 3,36 & $\mathbf{0 , 2 9}$ & Sangat Puas & \\
\hline \multirow[t]{2}{*}{23} & Perhatian terhadap kebutuhan wisatawan & 4,10 & 4,01 & $\mathbf{0 , 0 9}$ & Sangat Puas & \\
\hline & Nilai rata-rata & $\mathbf{3 , 8 8}$ & 3,69 & $\mathbf{0 , 1 9}$ & Sangat puas & $\mathbf{0 , 1 9}$ \\
\hline \multicolumn{7}{|c|}{ Rata-rata Persepsi $(X)=$ dan Ekspektasi $(y)=$} \\
\hline & Rataan Rata-rata & $\mathbf{3 , 8 3}$ & 3,90 & $-\mathbf{0 . 0 7}$ & Belum Puas & \\
\hline
\end{tabular}

Sumber: Hasil Pengolahan Data, 2016

Keterangan:

$\mathrm{NP}=$ Nilai rata-rata pelayanan yang dirasakan

$\mathrm{NE}=$ Nilai rata-rata pelayanan yang diharapkan, $\mathrm{NS}=$ Nilai Kepuasan . 
secara optimal. Hasil penelitian ini juga menggambarkan bahwa ada 15 aspek pelayanan yang belum memenuhi harapan wisatawan atau wisatawan belum merasa puas dan 8 aspek pelayanan yang sudah memberikan nilai kepuasan bagi wisatawan domestik.

Berdasarkan hasil pembahasan pada lima dimensi kualitas pelayanan, maka dapat disimpulkan bahwa dimensi yang memerlukan prioritas penangan sesuai dengan tingkat kepuasan wisatawan domestik terhadap kinerja tiga belas perusahaan arung jeram di Sungai Ayung adalah dimensi kehandalan / Reliability. Dimensi ini yang mencakup kemampuan karyawan, ketersedian materian, standar peralatan dan ketepatan waktu pelaksanaan, merupakan aspek yang secara tidak langsu mempengaruhi kepuasan dan kenyamanan wisatawan sehingga dimensi ini perlu mendapat perhatian dan penanganan yang serius dari pihak pengelola

\subsection{Hasil Importance Performan Analysis (IPA)}

Untuk mengetahui indikator aspek pelayanan yang dianggap penting, maka digunakan analisis Kepentingan Kinerja (Importance Performan Analysis) dengan menggunakan diagram Kartesius untuk melihat letak hubungan penilaian kinerja pada aspek pelayanan dengan tingkat kepentingan/harapan wisatawan domestik terhadap 13 perusahaan arung jeram di Sungai Ayung. Menurut data pada diagram Kartesius menyatakan bahwa ada 1 aspek pelayanan yang berada pada kuadran I, 9 aspek pelayanan pada kuadran II, pada kuadran III terdapat 9 aspek pelayanan, dan pada kuadran IV ada 4 aspek pelayanan.

\subsection{Upaya-upaya untuk meningkatkan kualitas pelayanan.}

Menurut diagram kartisius terdapat beberapa aspek pelayanan yang kualitasnya kurang memuaskan bagi wisatawan sehingga membutuhkan penanganan dan perhatian yang serius dari pihak pengelola dalam memenuhi harapan dan keinginan wisatawan sehingga kepuasan dapat tercapai. Ada 15 variabel atau indikator yang termasuk belum memenuhi kepuasan wisatawan diantaranya adalah: Kejernihan air dan debit air di Sungai Ayung masih kurang, kebersihan tempat makan (restaurant) dan coffee break kurang bersih, kebersihan kamar ganti, kamar mandi dan toilet serta ketersedian air bersih yang digunakan masih kurang bersih, kebersihan fisik gedung kantor, kebersihan dan kenyamanan ruang tunggu dan tempat parkir, penampilan karyawan, ketepatan waktu pelaksanaan, respon karyawan terhadap keluhan wisatawan, kemampuan karyawan dalam memberikan pelayanan kurang memuaskan dan aspek peralatan yang sesuai dengan standar keselamatan dan kenyamanan wisatawan kurang memuaskan. Sehingga di perlukan beberapa upaya-upaya guna meningkatkan kualitas pelayanan, diantaranya:

a) Memberikan pemahaman kepada karyawan dan masyarakat lokal 


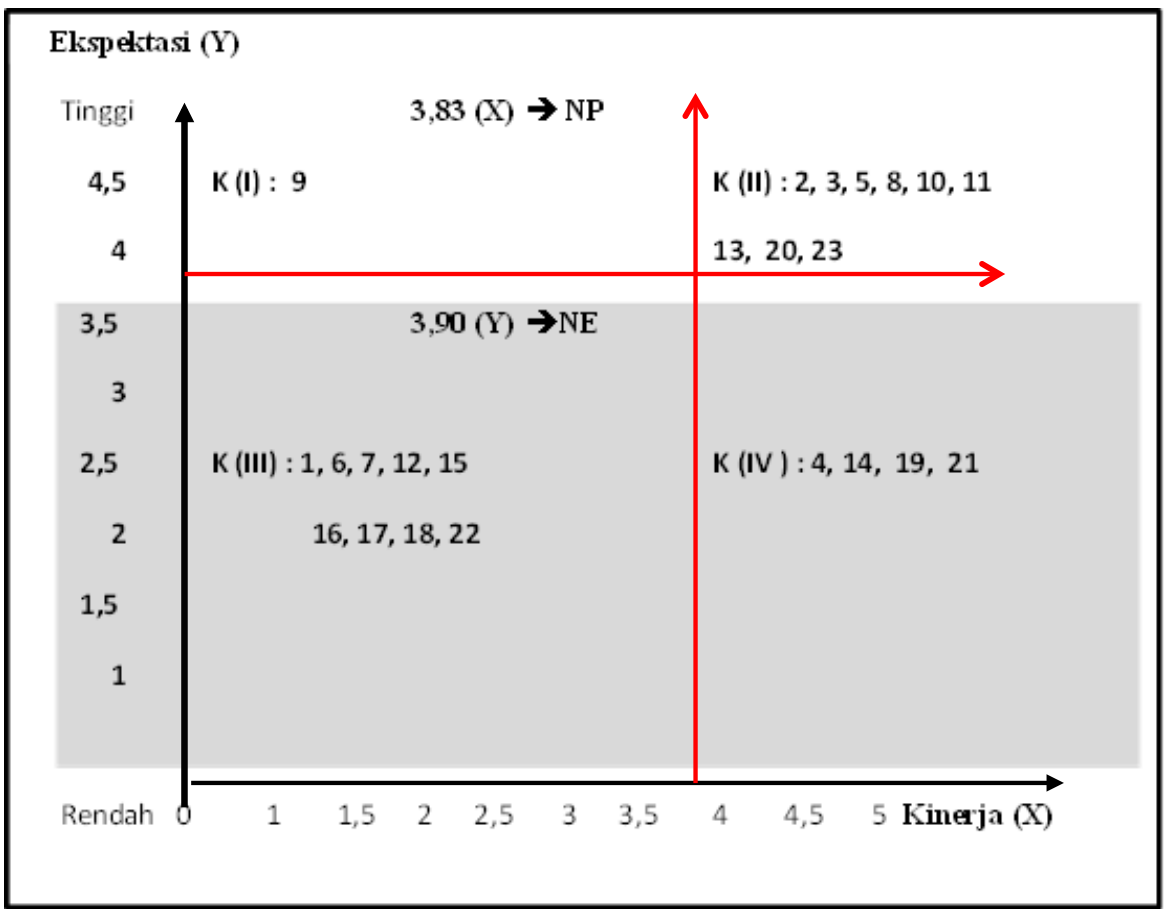

Sumber: hasil pengolahan data,2016

tentang pentingnya menjaga kebersihan dan kelestarian lingkungan di sepanjang Sungai Ayung untuk pariwisata berkelanjutan.

b) Pihak pengelola, karyawan dan wisatawan untuk selalu menjaga kebersihan di lokasi kegiatan mulai dari lokasi awal sampai akhir kegiatan untuk diperhatikan dengan baik dengan membiasakan karyawan untuk memungut sampah, menambah keranjang sampah, mencegah hewan liar masuk ke area vital.

c) Pihak pengelola untuk selalu menjaga kualitas produk arung jeram yang ditawarkan mulai dari kualitas peralatan yang digunakan sesuai dengan standar internasional dan adanya jaminan atau asuransi keselamatan bagi wisatawan.

d) Para pengelola dan stekaholder untuk dapat memotivasi seluruh karyawannya dalam hal peningkatkan profesionalisme pada waktu memberikan pelayanan, merespon setiap keluhan wisatawan dan memberikan informasi yang benar dan akurat serta melatih sikap karyawan agar mampu menunjukkan rasa simpatik kepada wisatawan jika wisatawan menemukan masalah selama mengikuti kegiatan arung jeram.

e) Selalu melakukan evaluasi terhadap setiap saran atau masukan yang diberikan oleh konsumen. 


\section{Kesimpulan dan Saran}

Berdasarkan pemaparan pada hasil dan pembahasan maka dapat disimpulkan sebagai berikut:

Pertama, perspektif wisatawan domestik tentang kualitas pelayanan yang diperoleh selama mengikuti kegiatan arung jeram mendapatkan hasil selisih $(0,07)<0$. Hal ini mengartikan bahwa kualitas pelayanan pada perusahaan arung jeram tersebut belum sepenuhnya mampu memenuhi harapan wisatawan.

Kedua, dimensi yang memerlukan prioritas penanganan sesuai dengan tingkat kepuasan wisatawan domestik terhadap tingkat kinerja di tiga belas perusahaan arung jeram di Sungai Ayung adalah dimensi kehandalan/ reliability.

Ketiga, data pada diagram Kartesius menyatakan bahwa ada 1 aspek pelayanan yang berada pada kuadran I yang memerlukan prioritas utama dalam penanganan, pada kuadran II terdapat 9 aspek pelayanan yang prestasinya perlu ditingkatkan, pada kuadran III terdapat 9 aspek pelayanan yang prestasinya masih rendah, dan pada kuadran IV yang prestasinya berlebihan ada 4 aspek pelayanan.

Berdasarkan kesimpulan di atas maka saran yang dapat diajukan dalam penelitian ini adalah kepada pihak pengelola arung jeram di Sungai Ayung untuk: (1) terus meningkatkan kualitas pelayanannya kepada konsumen atau wisatawan terutama aspek pelayanan yang meliputi lima dimensi yaitu dimensi bukti langsung, kehandalan, daya tanggap, jaminan, dan empati sehingga kepuasan wisatawan dapat tercapai; (2) terus melakukan inovasiinovasi terutama dalam hal variasi produk sehingga wisatawan merasa nyaman dan tertarik untuk membeli produk yang ditawarkan; (3) terus memotivasi dan memberikan pemahaman kepada tenaga kerjanya untuk meningkatkan kompetensi mereka terutama dibidang pelayanan prima sehingga kepuasan wisatawan dapat tercapai.

\section{Ucapan Terima Kasih}

Penulis menyampaikan ucapan terima kasih kepada Prof. Dr. I Nyoman Darma Putra,M.Litt. sebagai Pembimbing I dan Dr. Ni Made Eka Mahadewi,M.Par.,CHE dan Pembimbing II dalam riset penulisan tesis saat menempuh pendidikan di Prodi S2 Kajian Pariwisata Universitas Udayana. Prof. Dr. Ir.Made Antara,MS, Prof. Dr. Ir. IGP. Wirawan, M.Sc, dan Dr.I Nyoman Sukma Arida, M.Si selaku penguji yang juga memberikan masukan, saran, dan koreksi. Ucapan terima kasih juga penulis sampaikan kepada seluruh pihak yang telah membantu sehingga penelitian ini terlaksana. 


\section{Daftar Pustaka}

Amelda, Pramezwary \& Rudyanto. 2012. "Kajian Literatur Wisata Petualangan" (Jurnal) Hospitour Vol III No.2. Diakses tanggal 20 July 2014.

Dyatmika Justitia, Dewa Putu. 2013.”Dampak Keberadaan Wisata Rafting Terhadap

Kehidupan Sosial Ekonomi Masyarakat Desa Kedewatan, Ubud” (Skripsi). Nusa

Dua: Sekolah Tinggi Pariwisata Bali.

Dinas Pariwisata Provinsi Bali 2016. Bali Tourism Statistic. Denpasar: Dinas Pariwisata Provinsi Bali.

Jennings, Gayle. 2007. Water - Based Tourism, Sport, Leisure, and Recreation Experiences. UK: Burlington. Elseiver Inc.

Lastara, I M. 1997. Peraturan Kepariwisataa., Bali: PT Mabhakti Offset.

Marpaung, Happy.2002. Pengetahuan Kepariwisataan. Bandung: Alfabeta.

Pitana, I Gde dan Gayatri G. 2005. Sosiologi Pariwista. Kajian sosiologis terhadap struktur, system dan dampak - dampak pariwisata. Yogyakarta: Andi

Purnama Dewi, Selna Sari. 2013."Pengaruh Packaging Terhadap Proses Keputusan Pembelian Paket Wisata Olahraga Rafting Arus Liar" (Skripsi). Bandung: Universitas Pendidikan Indonesia, repository.upi.edu..

Rangkuti, Freddy. 2003. Measuring Customer Satisfaction, Gaining Customer relationship Strategy, Jakarta. PT Gramedia Pustaka Utama

Sihite, Richard. 2000. Tourism Industry. Surabaya: SIC.

Sirait, M.T dan Budi D.K.200o. Tata Niaga Usaha Perjalanan. Jakarta: PT Pradya Paramita.

Supranto, J. 2006. Pengukuran Tingkat Kepuasan Pelanggan Untuk Menaikan Pangsa Pasar. Jakarta: PT RINEKA CIPTA.

Schiffman, L.G dan Kanuk, Lesley L, 2007. Consumer Behavior. New Jersey: Parason Prestice Hall.

Simamora, B. 2004. Panduan Riset Perilaku Konsumen, Jakarta: PT Pustaka Gramedia Utama.

Tjiptono, Fandy. 2008. Service Management, Mewujudkan layanan Prima. Yogyakarta: ANDI.

\section{Profil Penulis}

Ni Putu Evi Wijayanti lahir di Denpasar tanggal 6 September 1978, Menyelesaikan program Diploma III di Sekolah Tinggi Pariwisata Nusa Dua Bali, jenjang S1 di Sekolah Tinggi Ilmu Manajemen Indonesia Handayani Denpasar, dan S2 di Kajian Pariwisata Universitas Udayana. Saat ini bekerja sebagai PNS atau Dosen di Program Studi Manajemen Bisnis Perjalanan dan Manajemen Konvensi dan Perhelatan / MICE, Sekolah Tinggi Pariwisata Nusa Dua Bali. Email: putueviwijayanti@gmail. com

I Nyoman Darma Putra adalah guru besar Fakultas Ilmu Budaya dan Ketua Program Studi Magister Kajian Pariwisata, Universitas Udayana. Darma menulis beberapa 
buku biografi tokoh pariwisata Bali dan menyunting beberapa buku, termasuk Pariwisata Berbasis Masyarakat Model Bali (2015) dan bersama Siobhan Campbell mengedit buku Recent Developments in Bali Tourism: Culture, Heritage, and Landscape in an Open Fortress (2015). Bersama Diah Sastri Pitanatri, Darma menulis buku Wisata Kuliner, Atribut Baru Destinasi Ubud (2016). Email: idarmaputra@ yahoo.com

Ni Made Eka Mahadewi saat ini bekerja sebagai PNS dosen di Program Studi Destinasi Pariwisata Sekolah Tinggi Pariwisata Nusa Dua Bali. Jabatan saat ini sebagai wakil ketua 1 (puket 1) yang membidangi bagian akademik dan kurikulum. Email: eka. mahadewi@gmail.com 